А. А. Бессолицын

Институт российской истории РАН, Институт общественных наук РАНХиГС, г. Москва, Российская Федерация

\title{
ЗАРОЖДЕНИЕ И РАЗВИТИЕ ИНСТИТУТА ПОСТАВЩИКОВ ДВОРА ЕГО ИМПЕРАТОРСКОГО ВЕЛИЧЕСТВА
}

Аннотация. Целью данной статьи является попытка рассмотреть процесс формирования института Поставщиков Императорских Дворов, который начал реально развиваться в России во второй половине XIX - начале XX вв.

С помощью этого института, государство, используя методы непрямого воздействия на рыночные сферы хозяйствования, сумело не только сформировать механизм обеспечения качественными товарами и услугами представителей высшей знати, но и способствовало в целом развитию различных форм частного предпринимательства.

В качестве примера успешной деятельности предприятия, получившего звание Поставщика Двора Его Императорского Величества рассмотрена деятельность Акционерно-паевого предприятия «Товарищество А. И. Абрикосова Сыновей», которое получив это звание в самом конце XIX в. сумело вплоть до 1917 г. значительно упрочить свое положение на рынке. Даже в годы Первой мировой войны фирма А. И. Абрикосова, несмотря на то, что покупательная способность населения в условиях войны объективно снизилась, работала с прибылью и сумела не только сохранить, но даже увеличить капитализацию предприятия, при этом выплачивая акционерам значительные дивиденды.

В условиях высочайшей конкуренции это звание зарабатывалось, прежде всего, высочайшим качеством поставляемых продуктов, товаров и услуг, без- 
упречной деловой репутацией и стало фирменным знаком элиты торгово-промышленного мира дореволюционной России.

Звание Поставщик Двора Его Императорского Величества являлось также своеобразным знаком качества для массовых потребителей, что, в свою очередь, усиливало конкуренцию и стимулировало производство данных товаров и услуг.

Кююевые слова. Институты, поставщик Двора Его Императорского Величества, Товарищество «А. И. Абрикосова Сыновей», конфликты интересов, кондитерская промышленность, дивиденды.

\section{A. A. Bessolitsyn \\ Institute of Russian History RAS, RANEPA, Institue of Social Sciences, Moscow, Russian Federation}

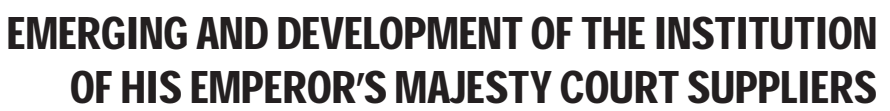

Abstract. The purpose of this article is the attempt to consider the process of formation of the institution of Emperor's Courts suppliers that began to develop in Russia during the second half of $19^{\text {th }}-$ beginning of $20^{\text {th }}$ centuries.

With the help of this institution the state, using the methods of indirect influence on the market spheres of economy, not only managed to form a mechanism of providing high-quality products and services to the representatives of the supreme nobility, but also contributed to the development of various forms of private entrepreneurship as a whole.

The activity of Joint-stock company "Partnership of A. I. Abrikosov and Sons" that received the above mentioned status at the end of $19^{\text {th }}$ century and managed to significantly strengthen its position on the market up to 1917, is used as an example of successful activity of the company that received the status of His Emperor's Majesty Court supplier. Even during the First World War when the purchasing ability of the population objectively de- 
clined the firm of A. I. Abrikosov was making profit and managed not only to save, but also to increase the capitalization of the company and pay significant dividends to its shareholders.

In the conditions of the highest competition, this status was earned mostly due to the highest quality of the provided products, goods and services, excellent business reputation and became a brand of the elite of trade and industrial world of pre-revolutionary Russia.

The status of His Emperor's Majesty Court supplier served also as a certain quality mark for mass consumers, which, in its turn, strengthened the competition and stimulated the production of the respective products and services.

Keywords. Institutions, His Emperor's Majesty Court supplier, Partnership of A. I. Abrikosov and Sons, conflicts of interest, confectionary industry, dividends.

Институциональный подход дает ключ к пониманию многих явлений и процессов, происходивших в истории России, в том числе процесса зарождения и развития такого явления, как институт поставщиков Двора Его Императорского Величества, в основном сформировавшегося во второй половине XIX - начале XX вв.

В настоящее время в рамках современного институционализма наиболее распространенной является трактовка Дугласа Норта, который определяет Институты, как «правила игры» в обществе, или, выражаясь более формально, созданные человеком ограничительные рамки, которые организуют взаимоотношения между людьми [9, с. 17].

Институты проявляются как в виде формальных законов (конституции, законодательства, права собственности), так и в виде неформальных правил (традиции, обычаи, кодексы поведения). При этом формальные институты - это институты, созданные властью, они часто создаются, чтобы служить интересам тех, кто контролирует институциональные изменения 2018. T. 19, № 1. C. 7-30 
в смешанной экономике, а неформальные (общественные) институты - это институты, которые несоздаются властью, а развиваются стихийно. Они реализуют идеологические и духовные потребности, влияют на общественные организации и экономическое поведение.

Экономические изменения, точно также, как и политические, и социальные, происходят под влиянием институтов, которые должны постоянно меняться. Не является в этом смысле исключением и институт Поставщиков Двора Его Императорского Величества, который начал реально формироваться в России во второй половине XIX века при активном участии и влиянии государства. Поэтому он в значительной степени носил формальный характер. Это были - нормы, правила и механизмы, выработанные канцелярией Министерства Императорского Двора и позднее Министерства финансов с целью поощрения лучших производителей товаров, поставляемых Императорскому двору и Великокняжеским дворам.

В данной статье предпринята попытка рассмотреть процесс формирования института Поставщиков Императорских Дворов. С помощью этого института, государство, используя методы непрямого воздействия на рыночные сферы хозяйствования, сумело не только сформировать механизм обеспечения качественными товарами и услугами представителей высшей знати, но и способствовало в целом развитию различных форм частного предпринимательства.

\section{Исторический экскурс}

Традиционно, начиная еще с XVI века обеспечением нужд царского двора занимался Дворцовый приказ в введении которого находились производства, поставлявшие необходимые товары и продукты. Так полотно для царского двора изготовлялось жителями дворцовых слобод и сел - Кадашевской слободы в Замоскворечье, тверской Хамовной слободы и двух сел Ярослав- 
ского уезда. Каждая слобода (или село) должны были поставлять для нужд двора «оброк» - определенное количество ткани установленного ассортимента, - который в действительности таковым не являлся, так как за него выдавалась определенная плата. Каждый хозяин выполнял часть общей работы - «дело». Помимо освобождения от государственных повинностей за каждое «дело» он получал «хлебное жалованье» (т. е. бесплатное продовольствие) и определенную денежную сумму [4, с. 119].

Подобные отношения между государством и частными предпринимателями, хотя в целом и носили традиционный характер, но в их развитии уже можно увидеть начало процесса зарождения формальных норм, поскольку лишь после полного удовлетворения потребностей царского двора, полотна, которые изготовлялись, например, мастерами Кадашевской слободы поступали в рыночную продажу [10, с. 476].

Тем не менее, формирование института Поставщика в его традиционном понимании в России начинается только в XVIII веке. Первоначально отношения между хозяйственными подразделениями Двора и частными предпринимателями складывались не на основе разработки новых юридических норм и правил, а на основе принципа прецедента. Как правило, если предприниматель из года в год выполнял все требования, предъявляемые к качеству, номенклатуре и срокам поставок товаров и услуг, то эти заказы возобновлялись, что было, безусловно, выгодно поставщикам. Выгодно, прежде всего, потому что содержание Императорского Двора стоило значительных средств, источником которых в основном был государственный бюджет. Именно за эти средства велась постоянная конкурентная борьба. Но при этом все усилия по получению статуса поставщика Императорского Двора оправдывались как стабильными заказами, так и самим фактом наличия этого высокого статуса. 
Процесс юридического оформления Института поставщиков протекал медленно и фактически занял более ста лет. В 1704 г. при Петре I, создается специальная Придворная контора, которая занималась общим хозяйственным управлением Двора и одной из важных обязанностей имела заботу о поставках товаров ко Двору главным образом из-за границы. Для этих целей привлекаются частные, в основном иностранные, предприниматели.

В 1742 г. при дворе Елизаветы Петровны была учреждена должность Придворного фактора (гоф и камер фактора) для выписывания из-за границы всех потребных для Двора товаров. Должность придворного фактора занимал также иностранный купец, который «... имел право продавать товары кому пожелает, содержать магазины и лавки и вести обширную торговлю помимо исполняемых им придворных обязанностей» ${ }^{1}$. Эта должность просуществовала до конца XVIII века. За это время значительно выросла и окрепла отечественная промышленность, чрезвычайно расширилась русская торговля и товары начали постепенно доставляться к Высочайшему Двору и русскими торговыми и промышленными деятелями.

Значительный вклад в формирование института поставщиков внесла Екатерина II, поскольку именно она впервые в России юридически оформила принцип частной собственности. Новый курс в экономике был провозглашен еще в 1760-е гг. Причем Екатерина высказывалась не только в пользу свободы экономической деятельности и освобождения частной инициативы, она решительно одобряла либеральный принцип частной собственности [8, с. 31]. Окончательно этот

1 В память Трехсотлетия царствования Дома Романовых. 1613-1913 гг. : юбилейный альбом Поставщиков Двора Его Императорского Величества и Великокняжеских Дворов. СПб., 1914. 55 c. 
принцип был закреплен в Указе 1780 г. Согласно которому: «Принадлежащие частным людям собственные фабрики и мануфактуры не инако разумеемы были, как собственное имение, которым каждый может свободно распоряжаться, не требуя никакого дозволения от начальства» [7, с. 20]. Подобная политика способствовала развитию конкуренции на внутреннем товарном рынке, что позволяло приобретать для содержания Двора товары и продукты лучшего качества по умеренным ценам.

Этот принцип получил дальнейшее развитие в период правления Павла I (1796-1801 гг.). По Положению, принятому 30 декабря 1796 г., основная часть продуктов и напитков стала закупаться по подрядам от Поставщиков на наиболее выгодных для Двора условиях. Выгодность условий определялась либо путем анализа рыночных цен, либо Дворцовым ведомством, которое организовывало открытые тендеры. Собственные придворные службы, производящие продукты питания, были окончательно ликвидированы, также упразднили должности винокуров, медоставов, пивоваров, квасников, купоров и т. Д. Специалисты из Гофмаршальской части внимательно отслеживали среднегородской уровень цен и контролировали, чтобы при закупках продуктов на кухню не допускалось переплат [5, с. 234-235].

Далее, уже при Александре I (1801-1825 гг.) Высочайшим Манифестом от 1 января 1807 г. «О выгодах, дарованных купечеству», первостатейному купечеству было пожаловано право приезда ко Двору, а указом 1824 г. это право была распространено на купцов первой гильдии вообще. Именно тогда купцы и фирмы, получившие соизволение доставлять товары ко Двору, получают право именоваться «Поставщик Двора Его Императорского Величества»².

${ }^{2}$ В память Трехсотлетия царствования Дома Романовых. 1613-1913 гг. 
Тем не менее, это право еще не регламентировалось каким-либо нормативным документом, а целиком зависело от «Высочайшей воли». Как правило, это были официальные просьбы на имя Министра двора о ходатайстве перед Императором звания Поставщика с правом иметь на изделиях или предприятии Российский Герб.

Таким образом, фактически звание и сам термин «Поставщик Императорского двора» появляется в документах уже в первой четверти XIX века, однако, юридическое оформление этого звания вводится только в 1856 г., когда Министерство двора разработало четкую процедуру получения данного права [5, с. 234]. В этом же году утверждается форма знака поставщика - Государственный Герб. Именно с этого момента можно говорить о создании формального института поставщиков Двора. В рамках данного процесса утверждается Регламент получения почетного звания, а также вид и форма знака придворного поставщика. В дальнейшем, по сути, идет детализация и совершенствование установленной процедуры.

С 1862 г. официально разрешается размещать Государственный герб на вывесках и изделиях, тем предпринимателям, которые в течение не менее 8-10 лет (без перерыва) поставляли свою продукцию по заказу Двора. Звание «Поставщика Высочайшего Двора» давалось лицу, доказавшему добросовестность, трудолюбие и способность и не иначе как на весь период поставок (к этому времени Государственный герб на своих вывесках использовали уже порядка 45-ти предпринимателей).

В 1884 г. последовало Высочайшее повеление распространить правила для получения звания поставщиков Высочайшего двора и на поставщиков Великокняжеских дворов. Это повеление окончательно стандартизировало процедуру получения звания придворного поставщика и поставщиков Великокняжеских дворов [11, с. 8]. 
Таким образом, можно говорить в целом о завершении формирования данного института с точки зрения закрепления юридических норм и правил. В дальнейшем процедура получения звания хотя и претерпевала определенные коррективы, но принципиально уже не менялась. Например, после коронации Николая II и Александры Федоровны в октябре 1894 г. помимо звания Поставщик Двора Его Императорского Величества, начиная с 1895 г. с Высочайшего разрешения стало присуждаться еще одно звание: «Поставщик Ея Императорского Величества» с правом иметь на вывеске изображение Государственного герба. В результате у каждой из императриц начал формироваться свой штат поставщиков.

В 1901 г. было разработано и утверждено новое (цветное) изображение знака поставщика Высочайшего и Великокняжеских дворов (он не менялся с 1856 г.). В новом знаке под щитом размещалась лента, на которой указывался его статус: «Высочайшего Двора», «Императрицы Марии Федоровны», «Императрицы Александры Федоровны» или Великих князей и княгинь. Также указывался год присвоения звания. Выдавалось и специальное удостоверение из Канцелярии Министерства Императорского двора с цветным изображением знака [11, с. 6-7].

Звание присваивалось по прошениям поставщиков дважды в год, на Рождество и на Пасху. Официально это звание было отменено уже Советской властью в 1922 г., когда уже в условиях НЭПа, некоторые возродившиеся фирмы стали употреблять это звание на своих вывесках.

\section{Механизм функционирования института поставциков}

К празднованию 300-летия Дома Романовых в 1913 г. был подготовлен Юбилейный альбом с упоминаниями 33-х иностранных и российских поставщиков Двора Его Императорского Величества. В числе этих 2018. T. 19, № 1. C. 7-30 
предпринимателей и фирм были указаны: Акционерное общество водочного завода Келлер и Ко (Санкт-Петербург), Винные погреба «Бартон и Гетье (Бордо, Франция), Товарищество Ростовской на Дону фабрики Я. С. Кушнарева, Товарищество чайной торговли и складов «Братья К. и С. Поповы» (Москва), Торговый Дом «Луи Редерер» (Реймс, Германия), Торговый Дом «I. Ротшильд и Сыновья» (Париж, Франция) и др. ${ }^{3}$

В начале 1915 г. Канцелярия Министерства Императорского двора составила относительно полный «Список Поставщиков Высочайшего Двора». Это было связано с тем, что Германия и Австро-Венгрия, а затем и Османская империя оказались противниками России в Первой мировой войне. Следовательно, подданные этих стран уже не могли быть поставщиками Российского Императорского Двора. Этот список впервые был обнародован в исследовании, подготовленном авторами В. В. Скурловым и А. Н. Ивановым. Всего в Списке, составленном к началу 1915 г., было учтено 1340 фирм и персон. Подсчеты, сделанные по материалам Списка, показывают, что среди поставщиков Императорского двора преобладали российские предприниматели (около 80 \%), а более 50 \% поставщиков приходилось на производителей продуктов питания и напитков, одежды и обуви, ювелирных изделий и предметов роскоши, парфюмерии, посуды и мебели $[11$, с. 4$]$.

Среди наиболее известных поставщиков можно назвать следующие фирмы: Производитель часов Павел Буре, Булочная Филиппова, Товарищество Прохоровской Трехгорной мануфактуры, Товарищество мануфактур П. М. Рябушинского с сыновьями, Фабрика ювелирных изделий К. Фаберже, Товарищество производства фарфоровых и фаянсовых изделий М. С. Кузнецова, Императорский фарфоровый завод, Товари-

${ }^{3}$ В память Трехсотлетия царствования Дома Романовых. 1613-1913 гг. 
щество парфюмерного производства «Брокар и Ко»., Водочные заводы П. А. Смирнова, Производство шампанских вин Л. С. Голицына, Товарищество по продаже чая «А. С. Губкин и А. Г. Кузнецов», Товарищество шоколада и чайных изделий паровой фабрики конфет Эйнем, Торговый дом «Братья Елисеевы», Пивоваренный завод «Корнеев, Горшанов и К» и др.

Однако перечень поставщиков не исчерпывался только представителями легкой и пищевой промышленности. Среди фирм и предприятий, представлявших интересы обрабатывающих и машиностроительных отраслей промышленности, были: Акционерное общество «Мануфактурная компания Зингер», Производители автомобилей Мерседес и Руссо-Балт, французская автомобильная фирма «Делоне-Бельвиль», Путиловский литейный завод, Тульский оружейный завод, Машиностроительный завод «Людвиг Нобель» и др.

В списках поставщиков можно найти и индивидуальных предпринимателей: сапожный мастер Василий Егоров из Кронштадта, изготовитель седел Федот Калаушин из станицы Баталпашинской, поставщик муки С. Д. Русанов из Ельца и др.

Среди поставщиков было достаточно много иностранцев. Их доля в общем числе составляла порядка $20 \%$. Первое место среди них занимали немецкие предприниматели. Вторую позицию среди поставщиков-иностранцев после Германии занимала Дания. В 1881 г. звание придворного поставщика получил датский предприниматель Петр Геринг, поставлявший в Петербург ликеры [5, с. 236].

Вся процедура рассмотрения и экспертизы документов предпринимателей на право именоваться «поставщиками Высочайшего Двора» сосредотачивалась в Канцелярии Министерства Императорского Двора. Собственно, этой процедурой и объясняется появление нескольких «орлов» на продукции известных 2018. T. 19, № 1. C. 7-30 
предпринимателей. Именно Канцелярия разрабатывала механизм получения звания, который сводился к следующему алгоритму:

- во-первых, в канцелярию Министерства Императорского Двора подавалось аргументированное заявление той или иной фирмы о желании получения звания поставщика Высочайшего Двора;

- во-вторых, рапорт той или иной заинтересованной хозяйственной структуры Министерства Императорского Двора (Кабинета Его Императорского Величества, Гофинтендантской конторы, Придворной Его Императорского Величества конторы, впоследствии Главного дворцового управления и др.) с просьбой поддержать ходатайство фирмы подавался непосредственно на имя министра Императорского Двора;

- в-третьих, Канцелярия Министерства Императорского Двора «готовила документы». Шли запросы в различные инстанции, вплоть до Департамента полиции МВД о «хозяйственном и моральном облике» фирмы.

В качестве условий предоставления звания рассматривались не просто исполнение поставок и работ для потребностей Двора, а непрерывность этих поставок на протяжении 8-10 лет, а также производство поставок или работ непосредственно лицом, ходатайствующим о получении звания и из предметов собственного производства. Учитывалась также успешность поставок или работ (исправное, добросовестное, по сравнительно малым ценам исполнение заказов).

Если все эти условия выполнялись, то решающее значение при принятии окончательного решения имело мнение «профильного» хозяйственного подразделения, с которым непосредственно работала заинтересованная фирма. Формально окончательное решение принимал министр Императорского Двора, а на деле «готовил документы» начальник Канцелярии Министерства Императорского Двора. При этом, как 
правило, до 50 \% заявлений соискателей по тем или иным причинам отклонялось.

Следует также подчеркнуть, что звание поставщика давалось «на физическое», а не на «юридическое лицо» и полностью зависело «от Высочайшего Его Императорского Величества благоусмотрения». Кроме этого, важнейшим положением было то, что звание поставщика давалось только на время реального сотрудничества с хозяйственными структурами Министерства Императорского Двора. При этом особо подчеркивалось, что это звание не передается по наследству «физическими лицами». Для сохранения его наследникам требовалось испрашивать особое Высочайшее разрешение [11, с. 6].

В качестве примера, иллюстрирующего процедуру рассмотрения просьбы о присвоении звания поставщика, можно привести переписку Заведующего канцелярией Министерства Двора с начальником Дворцового Управления по поводу присвоения звания Фабрично-торговому товариществу «А. И. Абрикосова Сыновей».

Надо отметить, что кондитерская промышленность вследствие увеличения потребления конфет и шоколада на рубеже XIX-XX вв. переходит из разряда фабрично-ремесленного производства в капиталистическую форму и выходит на народный рынок ${ }^{4}$. При этом «... разнообразные кондитерские изделия, доступные раньше для украшения стола какого-нибудь богача, теперь стали предметом массового фабрично-промышленного производства и доступными гораздо большему кругу лиц» [12, с. 105]. В больших городах открываются крупные предприятия по массовому производству кондитерской продукции, которые

${ }^{4}$ Главнейшие данные переписи г. Москвы 31 января 1902 г. Выпуск VI. Население Москвы по занятиям. Составлено Б. Д. Никитиным (под редакцией Статистического Отдела Московской Городской Управы). М. : Городская типография, 1907. С. 64. 
снабжают сладостями всю страну. В Москве к таким предприятиям относились Товарищество «А. И. Абрикосова Сыновей», «Эйнем», «А. Сиу и Ко» и «Реномэ»; в Петербурге - «Борман Жорж», «Карл Бездэка», «Виктория» и «Глория» [2, с. 44-90]. На 211 кондитерских предприятиях в 1900 г. трудилось 12366 человек [6, с. 53]. Основной капитал самых крупных акционерных кондитерских компаний страны («А. И. Абрикосова Сыновей», «Реномэ», «Сиу и Ко», «Борман Жорж», «Виктория», «Ефимов Валентин» в Киеве, «Ланковский и Ликоп» в Митаве) в 1902 г. составлял 3,4 млн. рублей ${ }^{5}$. Всего за пять лет, к 1907 г. основной капитал этих акционерных обществ увеличился до 4,5 млн. руб., т. е. вырос более чем на $30 \%{ }^{6}$.

Старейшим среди предприятий этой отрасли было Товарищество «А. И. Абрикосова Сыновей», которое работало в Москве с 1880 г. и входило в тройку крупнейших кондитерских фирм России. Помимо Москвы производства, фирменные магазины и склады Товарищества располагались в Санкт-Петербурге, Киеве, Одессе, Ростове-на-Дону, Нижнем Новгороде и Симферополе.

К моменту подачи ходатайства о присвоении звания поставщика основной капитал фирмы составлял 1 млн. руб., а прибыль за 1900 г. достигла почти 230 тыс. руб. На кондитерских фабриках Товарищества, расположенных в Москве и Симферополе работало 850 человек, которые производили шоколад, конфеты, печенья, бисквиты и другую кондитерскую продукцию [1, с. 1]. Ответом на ходатайство стало письмо от 5 ноября 1899 г. на бланке Канцелярии Министерства Импера-

5 Вся Россия. Русская книга промышленности, торговли, сельского хозяйства и администрации : торгово-промышленный адрес-календарь Российской империи. СПб. : Изд. А. С. Суворин, 1895. 1902. С. 2970.

${ }^{6}$ Совет съездов представителей промышленности и торговли : список действующих в России акционерных предприятий с указанием размера акционерных капиталов и размеров годовых взносов. СПб., 1907. C. 29. 
торского Двора на имя Начальника Московского Дворцового Управления следующего содержания: «Канцелярия Министерства Императорского Двора имеет честь просить Ваше Превосходительство сообщить надписью на прилагаемом при этом бланке сведения о производимых фабрично-торговом товариществе «А. И. Абрикосова Сыновей» к Высочайшему Двору поставках или об исполнении, по требованиям Московского Дворцового Управления, заказов или работ» .

На основании этого письма Московское Дворцовое Управление подготовило и направило 24 ноября 1899 г. в Канцелярию Министерства Императорского Двора следующие документы:

I. Сведения об исполненных поставках фабрично-торговым товариществом «А. И. Абрикосова Сыновей» кондитерских предметов собственной фабрики по требованиям Московского Дворцового Управления в течение последних лет с 1886 года по 1898 год включительно (всего за 12 лет).

В перечне указывались конкретные годы, в которые оказывались услуги, по какому случаю и какие предметы поставлялись и на какую сумму.

В течение десяти лет (ежегодно) фирма поставляла угощение воспитанникам и воспитанницам Московских учебных заведений, во время бесплатных спектаклей в Высокоторжественные дни в Московских театрах. Туда поставлялись конфеты, шоколад, разные напитки, бисквиты и мороженое на общую сумму 9532 руб. 95 коп.

Кроме того, оказывались разовые услуги по случаю Высочайших приездов в Москву и пребывания в Московских Дворцах Иностранных Высочайших Особ, при этом также указывался перечень поставляемых кондитерских изделий и их стоимость. Например, в

7 Товарищество А. И. Абрикосова Сыновей. Возражденные традиции качества жизни. URL: /http://abrikosov-sons.ru/postavschik_dvora ego_im. 
1900 г. во время пребывания Его Королевского высочества Наследника Итальянского Престола Принца Неаполитанского были поставлены конфеты и другие кондитерские предметы на сумму 48 руб. 60 коп., во время пребывания Его Величества Короля Румынского были поставлены те же предметы на сумму 40 руб. 25 коп. и т. п. Надо отметить, что это была устоявшаяся практика. Поставщиков Императорского Двора и тех, кто только желал им стать активно привлекали к проведению различных торжеств.

II. Анкета кандидата на звание «Поставщик Высочайшего Двора» включающая 7 вопросов, связанных с перечнем проведенных работ и поставок конкретных изделий, непрерывность этих поставок, на какую сумму и по каким ценам, на собственных ли производствах они произведены. На последний вопрос: «Заслуживает ли уважения ходатайство Товарищества «А. И. Абрикосова Сыновей» об испрошении звания поставщика Высочайшего Двора» был получен положительный ответ и в декабре 1899 г. Министерство Двора присвоило фабрично-торговому товариществу «А. И. Абрикосова Сыновей» звание «Поставщик Двора Его Императорского Величества ${ }^{8}$.

Надо отметить, что после присвоения этого звания основной капитал Товарищества вырос с 1 млн. руб. в 1900 г. до 2-х млн. в 1916 г. Прибыль только за 1914/15 гг. составила более 330 тыс. руб., а численность рабочих на предприятиях Товарищества к 1916 г. увеличилась до 900 человек [3, с. 59]. Все эти успехи были достигнуты даже несмотря на то, что покупательная способность населения в условиях Первой мировой войны значительно снизилась.

По официальным данным Министерства торговли и промышленности и Министерства финансов к

8 Товарищество А. И. Абрикосова Сыновей. Возражденные традиции качества жизни. URL:/http://abrikosov-sons.ru/postavschik_dvora ego_im. 
началу 1917 г. насчитывалось порядка 18 акционерно-паевых предприятий, деятельность которых, в той или иной степени, была связана с производством шоколада, конфет, бисквитов и других кондитерских изделий. Из этого количества, 6 фирм или 33 \%, в разное время получили звание Поставщика Высочайшего Двора, что свидетельствовало о высоком качестве производимой ими продукции. Это были, помимо Товарищества «Абрикосова Сыновей», Товарищество на паях «Георг Ландрин», Товарищество «Жорж Борман» (оба в Петрограде), а также Московское фабрики: Товарищество фабрик «А. Сиу и Ко», Товарищество на паях паровой фабрики шоколада, конфет и чайных печений «Эйнем» и Товарищество на паях кондитерской фабрики «Ивановы и Марков» [3, с. 59-67].

Все кондитерские предприятия входили в группу по обработке вкусовых и пищевых веществ и, несмотря на сложности военного времени (мобилизация рабочей силы, перераспределение ресурсов в сферу военного производства, ориентации государственных заказов на производство вооружения и снабжения армии и т. д.), в целом работали стабильно и даже показывали прибыль. Исключение составляли только винокуренные, пивоваренные, ректификационные и водочные заводы, которые в связи с введением сухого закона, показали убытки. Наиболее успешно в данной группе предприятий работали табачные фабрики, которые активно участвовали в тендерах на поставку в армию махорки. Что касается кондитерских предприятий, то они, практически не участвовали в этом процессе (некоторые фабрики правда получали заказы от военного ведомства на поставку в армию галет) и в основном реализовывали свою продукцию на свободном рынке. Однако, даже несмотря на кризис, который в годы войны испытывала сахарная промышленность, что повлекло за собой рост цен на сырье, производство кондитерских товаров продолжало стабильно расти. 2018. T. 19, № 1. C. 7-30 
Более того, ряд кондитерских фабрик даже увеличивали свой основной и запасной капитал, выплачивали дивиденды пайщикам и премии трудовым коллективам. Эта ситуация была характерна и для предприятий, которые являлись поставщиками Двора и, по определению, не могли экономить на качестве продукции, поскольку это автоматически приводило к потере высокого статуса.

Вот несколько характерных примеров: в Товариществе на паях «Георг Ландрин» чистая прибыль за 1915 г. составила более 166 тыс. руб. Из этих средств 77 тыс. руб. было выдало пайщикам в виде дивиденда и еще 10 тыс. руб. в виде премии правлению предприятия ${ }^{9}$; Товарищество «Жорж Борман», на предприятиях которого в Петрограде и Харькове трудились более 1500 человек получило за 1915 г. чистую прибыль в размере более 728 тыс. руб., из которых в дивиденд пайщикам было перечислено 320 тыс. руб. и на вознаграждение правления еще 45 тыс. руб. Кроме того, на улучшение была рабочих и служащих было перечислено дополнительно почти 73 тыс. руб. ${ }^{10}$; Товарищество Московских фабрик «А. Сиу и Ко» получило за 1915 г. чистой прибыли более 1,4 млн. руб. из них в дивиденд за 1915 г. было выдано 120 тыс. руб. из расчета по 12 руб. на пай. Кроме того, еще 128,5 тыс. руб. было перечислено в качестве вознаграждения правлению предприятия ${ }^{11}$. Кроме того, в декабре 1916 г. состоялось чрезвычайное собрание пайщиков Товарищества, на котором было принято решение увеличить основной капитал с 3 млн. до 4,5 млн. руб. ${ }^{12}$

Прибыль от производства в Товариществе на паях паровой фабрики шоколада, конфет и чайных печений «Эйнем», на котором трудились более 1,1 тыс.

9 Вестник финансов промышленности и торговли. 1916. № 20.

${ }^{10}$ Вестник финансов промышленности и торговли. 1916. № 34 .

11 Вестник финансов промышленности и торговли. 1916. № 39.

12 Биржа (Независимый прогрессивный орган). 1916. № 1-2. 
человек, с марта 1915 по 29 февраля 1916 г. составила почти 3.3 млн. руб. из них чистая прибыль 505 тыс. руб. В дивиденд было выплачено 180 тыс. руб., что составило 12 \% на пай ${ }^{13}$. Надо отметить, что дивиденд за 1914 г. на этом же предприятии составил всего 6 \% [3, с. 67]. Кроме того, в годы войны фирма «Эйнем» активно занимается благотворительной деятельностью: жертвует деньги, организует лазарет для раненых солдат, отправляет на фронт вагоны с печеньем и т. д.

Наконец, Товарищество на паях кондитерской фабрики «Ивановы и Марков» за 1915-1916 гг. получило прибыль от производства и магазинов в размере 891 тыс. руб., из них чистая прибыль составила почти 84 тыс. руб. В дивиденд было выплачено 28 тыс., в награду служащим 20,5 тыс. и еще 5 тыс. было перечислено в сберегательную кассу для оказания материальной помощи работникам предприятия ${ }^{14}$.

Таким образом, все кондитерские предприятия, получившие звание «Поставщик Двора Его Императорского Величества» в условиях Первой Мировой войны не только сохранили свое экономическое положение, но даже смогли его существенно улучшить. Подобная ситуация в целом сохранялась и на других предприятиях, но кондитерская промышленность объективно находилась в более сложном положении, поскольку в условиях войны не могла рассчитывать на заказы от государства для нужд армии.

\section{Конфликты интересов}

По мере того, как росла численность фирм и персон, которые претендовали на получение звания Поставщика, возникали конфликты интересов между различными ведомствами, которые курировали эту процедуру. Уже на рубеже 1850-1860-х гг. складывается практика, когда две государственные структуры -

${ }^{13}$ Вестник финансов промышленности и торговли. 1916. № 42.

${ }_{14}$ Вестник финансов промышленности и торговли. 1916. № 43. 2018. T. 19, № 1. C. 7-30 
Министерство Двора и Министерство финансов практически параллельно законодательно закрепляют за собой право разрешать использовать Государственный герб в рекламных целях, лучшим производителям товаром и услуг.

Одновременно с Министерством Двора, Министерство финансов фиксирует в Своде законов Российской империи различные формы поощрения лучших производителей товаров. В статье 205 Устава Промышленности, 2 часть XI тома Свода Законов перечислялись награды, которые могли получить «фабриканты»:

1) публичная похвала и одобрение в описании выставки;

2) денежные премии;

3) похвальные медали, нарочно для этого выбитые, золотые и серебряные, большие и малые;

4) право употребления государственного герба на вывесках и изделиях;

5) Высочайшее благоволение;

6) медали для ношения на шее, на орденских лентах, золотые и серебряные;

7) ордена [11, с. 5].

Этот конфликт интересов был разрешен следующим образом: за Министерством финансов (с 1905 г. Министерством торговли и промышленности) осталось право разрешения на использование Государственного Герба на вывесках и изделиях в основном победителями промышленных выставок. С 1829 по 1896 гг. в Москве, Санкт-Петербурге и Нижнем Новгороде состоялось всего шестнадцать Всероссийских торгово-промышленных выставок, в которых приняло участие около 20 тыс. фирм и отдельных предпринимателей. Что касается Министерства Императорского Двора, то за ним, по-прежнему оставалось право присвоения звания придворного поставщика.

Надо заметить, что случаи отступления от законодательных норм при получении этого звания носили 
достаточно постоянный характер. Самым «законным» нарушением юридической процедуры была высочайшая воля, которая в самодержавной России была выше любого закона.

Во второй половине XIX в. именно звание придворного поставщика Императорского Двора становится самым престижным званием в торгово-промышленном сообществе. Чиновники Канщелярии Министерства Императорского Двора были прекрасно об этом осведомлены и пользовались этим, проводя тендеры на различные поставки и работы для Императорского Двора. В свою очередь потенциальные поставщики Двора ожесточенно боролись за звание и шли подчас на сознательные убытки, занижая цены на свои товары и услуги. Однако они прекрасно представляли, что получение звания, так или иначе компенсирует все убытки, поскольку изображение двуглавого орла на бланке фирмы свидетельствовало о безупречном качестве товара.

\section{заключение}

Таким образом, в результате сложившейся на протяжении второй половины XIX - начала XX вв. практики жесткого отбора сформировался институт поставщиков Двора Его Императорского Величества.

С помощью этого института, государство, используя методы непрямого воздействия на рыночные сферы хозяйствования, сумело не только сформировать механизм обеспечения качественными товарами и услугами представителей высшей знати, но и способствовало в целом развитию различных форм частного предпринимательства.

В условиях высочайшей конкуренции это звание зарабатывалось, прежде всего, высочайшим качеством поставляемых продуктов, товаров и услуг, безупречной деловой репутацией и стало фирменным знаком элиты торгово-промышленного мира дореволюционной России. Звание Поставщик Двора Его Императорского 2018. T. 19, № 1. C. 7-30 
Величества давало возможность не только поставлять элитные продукты и товары, оказывать услуги царскому двору и великим князьям, но и являлось своеобразным знаком качества для других потребителей, что стимулировало производство данных товаров и услуг.

\section{Єписок использованной литературы}

1. Акционерно-паевые предприятия России в 1912 г. (по официальным данным) / под общ. ред. И. М. Кованько. - М., 1912. -669 c.

2. Акционерно-паевые предприятия России / под общ. ред. И. М. Кованько. - М., 1915. - 671 с.

3. Акционерно-паевые предприятия России : сост. по офиц. данным М-ва торговли и пром-ти и М-ва финансов / под ред. В. В. Лаврова. - М., 1917. - 608 с.

4. Бессолицын А. А. История российского предпринимательства : учебник / А. А. Бессолицын. - 3-е изд., перераб. и доп. - М. : Синергия, 2013. - 400 с.

5. Зимин И. В. Императорская кухня XIX - начало XX в. Повседневная жизнь Российского Императорского Двора / И. В. Зимин, А. Р. Соколов, И. И. Лаверзон. - М. : Центрополиграф, 2014. - 384 с.

6. Кафенгауз Л. Б. Эволюция промышленного производства России (последняя треть XIX в. - 30-е гг. XX в.) / Л. Б. Кафенгауз. - М. : Эпифания, 1994. - 845 с.

7. Лаппо-Данилевский А. С. Очерк внутренней политики императрицы Екатерины II / А. С. Лаппо-Данилевский. СПб. : Тип. М. М. Стасюлевича, 1898. - 65 с.

8. Леонтович В. В. История либерализма в России. 17621914 / В. В. Леонтович. - М. : Русский путь, 1995. - 548 с.

9. Норт Д. Институты, институциональные изменения и функционирование экономики / Д. Норт. - М. : Фонд экономической книги «Начала», 1997. - 190 с.

10. Перхавко В. Б. Торговый мир средневековой Руси / В. Перхавко. - М. : Academia, 2006. - 607 с.

11. Скурлов В. В. Поставщики Высочайшего двора / В. В. Скурлов, А. Н. Иванов. - СПб., 2002. - 72 с.

12. Сущенко В. А. Предпринимательство на трех этапах российской модернизации (вторая половина XIX - начало XXI в.): общее и особенное в исторической судьбе : монография / В. А. Сущенко. - Ростов н/Д. : Изд-во ЮФУ, 2011. $406 \mathrm{c}$. 
1. Kovan'ko I. M. (ed.). Aktsionerno-paevye predpriyatiya Rossii v 1912 g. (po ofitsial'nym dannym) [Joint-stock companies of Russia in 1912 (according to official data)]. Moscow, 1912. 669 p.

2. Kovan'ko I. M. (ed.). Aktsionerno-paevye predpriyatiya Rossii [Joint-stock companies of Russia]. Moscow, 1915. 671 p.

3. Lavrov V. V. (ed.). Aktsionerno-paevye predpriyatiya Rossii [Joint-stock companies of Russia]. Moscow, 1917. 608 p.

4. Bessolitsyn A. A. Istoriya rossiiskogo predprinimatel'stva [History of the Russian entrepreneurship]. $3^{\text {rd }}$ ed. Moscow, Sinergiya Publ., 2013. 400 p.

5. Zimin I. V., Sokolov A. R., Laverzon I. I. Imperatorskaya kukhnya XIX - nachalo XX v. Povsednevnaya zhizn' Rossiiskogo Imperatorskogo Dvora [Imperial «inner workings» of $19^{\text {th }}-$ early $20^{\text {th }}$ century. Daily life of the Russian Imperial Court]. Moscow, Tsentropoligraf Publ., 2014. 384 p.

6. Kafengauz L. B. Evolyutsiya promyshlennogo proizvodstva Rossii (poslednyaya tret' XIX v. - 30-e gg. XX v.) [Evolution of industrial production in Russia (the last third of the $19^{\text {th }}$ century 1930s)]. Moscow, Epifaniya Publ., 1994. 845 p.

7. Lappo-Danilevskii A. S. Ocherk vnutrennei politiki imperatritsy Ekateriny II [Essay on the domestic policy of the Empress Catherine II]. Saint Petersburg, M. M. Stasyulevich Publ., 1898. 65 p.

8. Leontovich V. V. Istoriya liberalizma $v$ Rossii. 1762-1914 [The history of liberalism in Russia. 1762-1914]. Moscow, Russkii put', 1995. 548 p.

9. Nort D. Institutions, institutional change and economic performance. Cambridge university press, 1990. (Russ. ed.: Nort D. Instituty, institutsional'nye izmeneniya i funktsionirovanie ekonomiki. Moscow, Fond ekonomicheskoi knigi «Nachala» Publ., 1997. 190 p.).

10. Perkhavko V. B. Torgovyi mir srednevekovoi Rusi [Trade world of medieval Russia]. Moscow, Academia Publ., 2006. $607 \mathrm{p}$.

11. Skurlov V. V., Ivanov A. N. Postavshchiki Vysochaishego dvora [Suppliers of the Imperial Court]. Saint Petersburg, 2002. $72 \mathrm{p}$.

12. Sushchenko V. A. Predprinimatel'stvo na trekh etapakh rossiiskoi modernizatsii (vtoraya polovina XIX - nachalo XXI v.): obshchee i osobennoe $v$ istoricheskoi sud'be [Entrepreneurship in three stages of the Russian modernization (the second half of $19^{\text {th }}-$ the beginning of $21^{\text {th }}$ century): common and special in historical destiny]. Rostov-na-Donu, 2011. $406 \mathrm{p}$. 


\section{Информация об авторе}

Бессолииын Александр Алексеевич - доктор экономических наук, профессор, ведущий научный сотрудник, Центр экономической истории, Институт российской истории РАН, 117292, г. Москва, ул. Дмитрия Ульянова, д. 19; РАНХиГС, Институт общественных наук, 119571, г. Москва, пр. Вернадского, 82, e-mail: A_Bessolitsyn@mail.ru.

\section{$\$ \pi$}

Alexander A. Bessolitsyn - D.Sc. in Economics, Professor, Lead Researcher, Centre of Economic History, Institute of Russian History RAS, 19, Dmitry Ulyanov str., Moscow, 117292, Russian Federation; RANEPA, Institue of Social Sciences, 82, Vernadsky avenue, Moscow, 119571, Russian Federation, e-mail: A_Bessolitsyn@mail.ru.

\section{Для цитирования}

Бессолицын А. А. Зарождение и развитие института поставщиков Двора Его Императорского Величества / А. А. Бессолицын // Историко-экономические исследования. - 2018. - Т. 19, № 1. - C. 7-30. - DOI: 10.17150/23082588.2018.19(1).7-30.

\section{7:4}

Bessolitsyn A. A. Emerging and Development of the Institution of His Emperor's Majesty Court Suppliers. Istorikoekonomicheskie issledovaniya = Journal of Economic History $\mathcal{E}$ History of Economics, 2018, vol. 19, no. 1, pp. 7-30. DOI: 10.17150/23082588.2018.19(1).7-30. (In Russian). 